\title{
カオス応答アトラクタのリカレンスプロットに基づく 構造物の損傷位置同定*
}

\author{
野村 泰稔 ${ }^{* 1}$, 森本 大貴 ${ }^{* 2}$, 日下 貴之 ${ }^{* 1}$, 古田 均*3
}

\section{Structural Damage Localization Based on Recurrence Plots of Chaotic Response Attractor}

\author{
Yasutoshi NOMURA ${ }^{* 1}$, Daiki MORIMOTO, Takayuki KUSAKA and Hitoshi FURUTA \\ ${ }^{* 1}$ Ritsumeikan Univ. Dept. of Mechanical Engineering \\ 1-1-1 Noji-higashi, Kusatsu, 525-8577 Japan
}

The field of vibration-based structural health monitoring involves extracting a feature which robustly quantifies damage-induced changes of the structural dynamics. Generally, the change of structural characteristics due to damage is analyzed by observing frequencies, mode shapes, damping, etc. However, the change of those modal features due to damage is minor, so that detecting the location of damage is difficult. Recently, an attractor-based monitoring system has been proposed. The recent study using chaotic excitation has demonstrated that the change of the attractor caused by damage is more sensitive than that of the most commonly used frequency and mode shape of the structure, in which the recurrence plot was applied successfully to the damage detection. However, damage localization has not been discussed sufficiently. An attempt in this study was made to develop a damage localization method using chaotic excitation and recurrence quantification analysis. It was demonstrated through experiment results that the proposed system makes it possible to detect damage locations.

Key Words : Recurrence Plots, Chaos, Structural Damage Localization, Attractor

\section{1. 緒言}

わが国では，1960 年頃から 1970 年代の高度経済成長期において橋梁や道路等に代表される社会基盤施設の整 備が大量に行われてきた ${ }^{(1)}$. 現在, これら既設の構造物の強度不足や劣化が問題視され，その維持管理をいかに 適切に行うかが重要な課題となってきている(2),(3). 社会基盤施設の維持管理を行う上で最も重要となるのが健全 性の評価であり，現在までに破壊・非破壊検査等の定期点検ベースの方法や健全性をリアルタイムに監視する技 術（構造ヘルスモニタリング）に関する研究が実施されている. 長期的な視野で，ライフサイクルコスト最小化 を目指寸社会基盤施設の維持管理計画を策定するためには，高度な技術を要する破壊・非破壊検査を実施する前 に, 診断対象の全体構造の健全性を把握し, 更なる詳細調査が必要な損傷箇所を的確に特定することが重要であ る.このような背景から, 振動応答計測に基づく構造ヘルスモニタリング手法が提案されている(4),(5),(6),(7). これら は計測自体の簡便さ, 振動応答は構造物の性能に直接関係していることから, 高度な破壊・非破壊検查による詳 細調查の事前調查として有効だと考えられる. 損傷に起因する構造特性の変化は, 一般的に周波数特性, モード 形状，減衰特性などを観察することで把握されるが，固有振動数の変化は損傷に対する感度が低く，損傷箇所の 特定はそれほど容易ではない. また損傷前後のモード特性の相関を調査寸る Modal Assurance Criteria (MAC) (7)よ び Coordinate Modal Assurance Criteria (COMAC)解析は全次モード特性を参照する段階で損傷に対する感度が劣化 してしまう.また, これらの先駆的な研究として, 構造物の応答から損傷の指標となる層剛性を逆解析により直

\footnotetext{
* 原稿受付 2013 年 4 月 29 日

${ }^{* 1}$ 正員, 立命館大学理工学部（广525-8577 滋賀県草津市野路東 1-1-1）

${ }^{* 2}$ 立命館大学大学院

*3 関西大学総合情報学部（干569-1095 大阪府高槻市霊仙寺町 2-1-1）

E-mail: y-nomura@fc.ritsumei.ac.jp
} 
接同定する方法が提案されている(8),(9),(10). ただし, 状態空間モデルを規定し, 逆解析により構造物の物理パラメ 一夕を推定する際，その推定精度は利用する逆解析手法やノイズレベルに大きく依存することが明らかにされて いる(9). これら以外にも, 自己回帰モデルを用いた方法 ${ }^{(11),(12)}$ ，ニューラルネットワーク ${ }^{(13)}$ を用いた方法, Wavelet

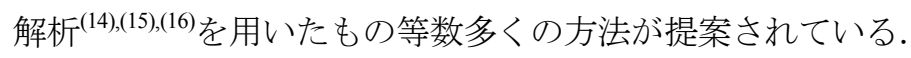

一方，近年新たな構造へルスモニタリング手法として，カオス応答アトラクタの定量評価に基づく方法が開発 されている(17),(18),(19). これらは構造物にカオス信号を入力し, その応答アトラクタのもつ特徵量を損傷前後で比較 することで，損傷発生を検出するものであり，文献 ${ }^{(18)}$ では診断対象の損傷に起因するカオス特徴量の変化はモー ド形状や固有振動数の変化と比較して大きいことが明らかにされている.ただし，これらの論文 ${ }^{(17),(18),(19)}$ では損傷 発生の検知に有効であることが示されているものの，全体構造から損傷位置を同定することに関しては十分に議 論されていない. また, 佐藤らは 3 次元フレームモデルを診断対象として, 損傷前後で得られる応答のアトラク タを交差させてリカレンスプロットおよびその特徴量である\%recurrence(以下, \%REC と記す)を評価することで, 損傷を有する要素を特定することに成功し，さらにはノイズに対して高いロバスト性を有することを数值実験に より明らかにしている(20). ただし，損傷位置によってはその位置の検出に失敗するケースも存在し，損傷位置を 同定するための特徵量の取り扱いや解析対象となる応答の選定等について十分に議論されているとは言い難い. 筆者らも数值実験を通じて, 損傷前後の応答アトラクタの評価法として, 交差予測誤差を計算し, 層レベルでの 剛性低下領域の損傷位置の同定に成功した ${ }^{(21)}$. ただし, 模型実験により応答に複数のモードが励起した場合, そ の応答から再構成されるアトラクタをそのまま評価しても，損傷位置同定に失敗することを確認した.

本研究では, カオス応答の低次モード成分に着目し, アトラクタの評価として Recurrence Quantification Analysis の内，リカレンスプロットを適用し，数值実験及び模型実験を通じて損傷位置同定を試みる.リカレンスプロッ 卜の評価指標である\%REC は計算時の閾值の設定により変化することから, 本研究では複数の閾值を設定 し, \%REC を標準化することを考える. また, 既往研究 ${ }^{(20)}$ では, 各計測点で算出された $\% R E C$ を損傷前後で比較 寸ることで損傷位置が評価されるが, 損傷前後で応答の波形構造や振幅レベルが大きく変化する場合, 損傷位置 の同定は困難となる，そこで本研究では，各計測点で得られる\%REC を損傷前後で比較するのではなく, 健全時 および診断時において計測されるデータに対して個別に標準化された％REC 評価することを考え，各状況下で， 計測点間の \%REC の減少・増加などの相対関係を評価し, その相対関係が損傷前後で異なることに着目する.

以下では，リカレンスプロットの説明とリカレンスプロットを用いた損傷位置同定アルゴリズムについて説明 し，実証試験において，構造物に一籄所および二箇所の損傷を与え，層レベルの損傷の位置を同定できるかどう か検討し提案手法の有効性を確認する.

\section{Recurrence Quantification Analysis}

リカレンスプロット ${ }^{(22)}$ とはアトラクタ上の各点間の相関関係を視覚化するものであり, 様々な分野で利用され ている. 同次元の 2 つのシステムから得られた時系列 $x$ と $y$ を比較する場合, 埋め込み次元 $m$, 遅れ時間 $\tau$ を決 定して各時系列から埋め込みベクトルを以下のように構成し, ディスタンスマトリクス $D_{i, j}$ を式(2)のように定義 する.

$$
\begin{aligned}
& \mathbf{x}(n)=(x(n), x(n+\tau), \ldots, x(n+(m-1) \tau)) \\
& \mathbf{y}(n)=(y(n), y(n+\tau), \ldots, y(n+(m-1) \tau)) \\
& D_{i, j}= \Theta(\varepsilon-\|\mathbf{x}(i)-\mathbf{y}(j)\|) \\
& \quad(i, j=1,2, \ldots, N \quad \text { or } \quad i=1,2, \ldots, N . j=i+1)
\end{aligned}
$$

ここで, $\Theta$ はへビサイド関数であり， $\varepsilon$ はアトラクタ軌道の接近の闇值となる半径である. $D_{i, j}=1$ となる点を リカレンスポイントと呼び, リカレンスプロットはリカレンスポイントを全ての $i$ と $j$ の組み合わせについてプ ロットすることで獲得される. リカレンスプロットを描くことで, 2 つのアトラクタ軌道の幾何学的な関係が視 覚的に得られる. リカレンスプロットはアトラクタをどう比較するかによって，2 種類に分けられ，式(2)内で同 
じアトラクタを比較する場合（ $\mathbf{x}=\mathbf{y} ）$ を Auto Recurrence Plots(ARP) と定義され，異なるアトラクタを比較する場 合 $(\mathbf{x} \neq \mathbf{y})$, つまり異なるアトラクタを交差する場合のリカレンスプロットは Cross Recurrence Plots と定義される.

図 1 にガウシアンノイズおよび代表的なカオス信号の一つであるローレンツ方程式の第一変数の Auto Recurrence Plots の例を示す．図 1 から明らかなように，ガウシアンノイズのリカレンスプロットは連続して対角 線方向にリカレンスポイントが発生していない，これは，時系列上に類似する軌道がないことを意味している. リカレンスプロットにおいて，ある点がプロットされることの意味は，その点に対応する時系列の軌道が類似し ていることを意味している．また対角線方向に連続してリカレンスポイントが現れることの意味は，連続して時 系列の軌道が似ていることを示している.

一方，ローレンツ方程式の場合，決定論に従う低次元カオスであることから，リカレンスポイントが対角線方 向に連続して発生していることが分かる. これらのリカレンスプロットの結果を定量化する手法として, Percent Recurrence $(\% R E C)^{(23)}$ が最も一般的に使用される. 具体的には, ディスタンスマトリクス $D_{i, j}$ が得られたとき,\%REC は式(3)で計算される.ただし，この場合， $D_{i, j}=D_{j, i}$ となり圥長性が高いため, 式(4)を用いて\%RECが計算される場 合もある.

$$
\begin{aligned}
& \% R E C=\frac{\sum_{i=1}^{N} \sum_{j=1}^{N} D_{i, j}}{N^{2}} \\
& \% R E C=\frac{2 \sum_{i=1}^{N-1} \sum_{j=i+1}^{N} D_{i, j}}{N(N-1)}
\end{aligned}
$$

$\% R E C$ は幾何学的には 2 つのアトラクタ軌道が接近する頻度を表し， 2 つ時系列間に類似パターンが発生す る頻度を意味する.

\begin{tabular}{|c|c|}
\hline Step 1 & $\begin{array}{l}\text { Input Chaotic signal to Structure and Observe } \\
\text { relative story acceleration }\end{array}$ \\
\hline Step 2 & $\begin{array}{l}\text { Extraction of the first mode vibration at all } \\
\text { measurement points }\end{array}$ \\
\hline Step 3 & Reconstruction of Attractor \\
\hline Step 4 & 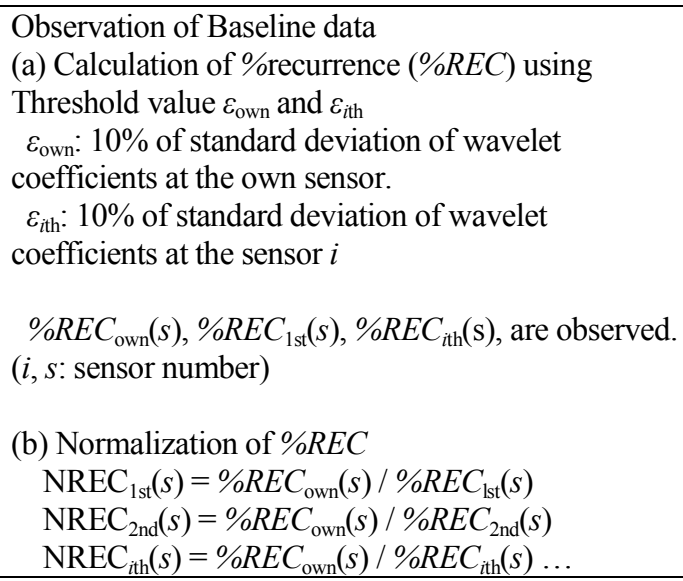 \\
\hline Step 5 & $\begin{array}{l}\text { Input Chaotic signal used in Step } 1 \text { to the damaged } \\
\text { structure and Steps } 2-4 \text { are performed. }\end{array}$ \\
\hline Step 6 & $\begin{array}{l}\text { Calculation of Damage Index } \\
\quad \operatorname{DI}(s) \\
\quad=\max \left[\frac{\operatorname{NREC}_{1 \text { st }}^{\text {damage }}(s)}{\operatorname{NREC}_{1 \text { st }}^{\text {Intact }}(s)}, \ldots, \frac{\operatorname{NREC}_{i \text { th }}^{\text {damage }}(s)}{\operatorname{NREC}_{i \text { th }}^{\text {Intact }}(s)}\right] \\
\operatorname{DI}(s)=1.0: \text { Intact } \\
\operatorname{DI}(s) \neq 1.0: \text { Damage }\end{array}$ \\
\hline
\end{tabular}

Table 1 Procedure of damage localization

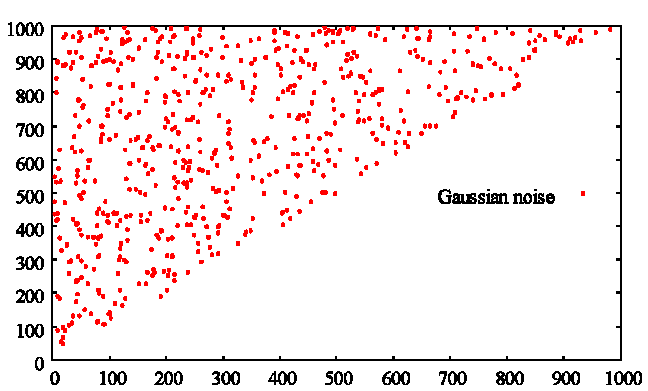

(a) Gaussian noise

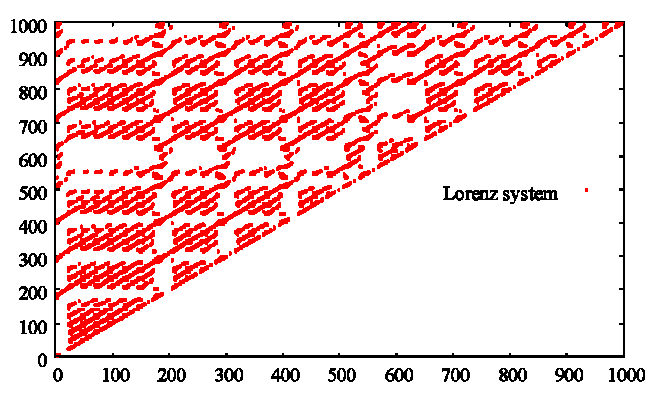

(b) Lorenz system

Fig.1 Recurrence plots 


\section{3. リカレンスプロットを用いた異常診断法}

リカレンスプロットを用いた損傷位置同定法の計算手順について表 1 にまとめる. まず，Step 1 において，構 造物にカオス信号を入力し, 各計測点で層間加速度応答を取得する.ここで, 層間加速度応答とは, センサ間の 相対加速度応答のことを意味し，塔上構造物を対象とする場合，上位のセンサの測定值と下位のセンサの測定值 の差のデータが層間加速度応答となり，本研究ではそれを上位のセンサの測定值としている．構造物にカオス信 号を入力すると, 複数の振動モードが励起され, 応答から再構成されるアトラクタを評価することで, 損傷発生 を感度良く検知することが可能である．ただし，後述する実証試験の数值実験において明らかにするが，これま での筆者らの事前検討により，複数のモードが励起する加速度応答の再構成アトラクタをそのまま評価すると損 傷の位置同定に失敗する場合があることを確認した．このことは複数のモードが損傷により変化するものの，モ ードの節の付近に損傷がある場合，その領域では損傷前後で応答の変化が小さいことが理由として考えられ，結 果として損傷位置を特定できなかった．このようなことから，本研究では，複雑に変化する全モードの振動成分 を含む応答を評価することを避け，節の存在しない振動忘答の 1 次モード成分のみを評価することとした．損傷 の規模および位置によっては，1 次モードの振動数，振幅レベルの変化は小さく，損傷がより高次モードに影響 を与える場合も当然考えられるが，損傷の影響により，1 次モードに対してもその応答の波形構造に変化が現れ ることから, 本研究では応答そのものを評価するのではなく, 1 次モードの振動成分のアトラクタに着目した．な お， 1 次モード成分の抽出に関してはローパスフィルタや実験モード解析などにより可能である，ただし，ロー パスフィルタを用いる場合は帯域設定に任意性が残り，実験モード解析を用いる場合，各モードのインパルス応 答を算出することが可能であるものの，それを算出する過程で必要となる減衰定数の初期值や重み行列の設定等 により, 各インパルス応答が変化することが考えられる.このような事から, 本研究では, Step 2 におて, 連 続ウェーブレット変換を用いて，1 次モード振動の波形構造を保持しているウェーブレット係数を算出し，それ を評価する. 具体的には, 計測された応答から FFT などにより 1 次モードの振動数を取得し，その值とマザーウ エーブレットの中心周波数が一致する際の Wavelet 係数の内, 実部の值を 1 次モード相当の振動成分（以下， 1 次モード振動と呼ぶ）と見なし，評価対象の時系列とした. Step 3 において，1 次モード振動からアトラクタを 再構成する. そして, Step 4 では複数の\%REC を計算し, 標準化した NRECを Baselineデータとして獲得する.\%REC の結果はディスタンスマトリックス $D_{i, j}$ を計算する際の閾值 $\varepsilon$ に依存する. また, 損傷規模により, 波形構造や 振幅レベルが健全時と比較して顕著に変化することから，健全時の応答から得られる閾值を用いて，解析対象の アトラクタを交差することで評価される Cross Recurrence Plots から\%REC を計算し損傷位置を推定すると, 必ず しも良い結果を与えるとは限らない，既往研究 ${ }^{(2)}$ では，診断時（損傷時）の応答を健全時の応答の標準偏差を用 いて基準化し，アトラクタを交差させて\%REC を評価し損傷の位置を同定しているが，損傷位置の特定に失敗す るケースが存在する。このような事から, 本研究では, 診断時に得られるアトラクタを評価する際に健全時の情 報を使用することなく，健全時および損傷診断時，それぞれの 1 次モード振動から複数の閾值を設定し, Auto Recurrence Plots から\%REC を計算し, それらを標準化した NREC を計算する. 閾值は, 各\%RECを基準化するた め, 全ての計測点から 1 次モード振動の標準偏差を計算し，その $10 \%$ の值とした．そして，それぞれの閾値を用 いて, \%REC を計算する. 例えば, 表 1 に示される\%REC $\mathrm{own}(s)$ は, 第 $s$ 番目のセンサで獲得されるアトラクタに 対して計算される\%RECである。この際，閾值は自分自身のセンサ（第 $s$ 番目のセンサ）で獲得された 1 次モー ド振動の標準偏差の $10 \%$ の值である。つまり, \%RE $C_{\mathrm{own}}(s)$ とは, 閾值を決定する際に用いられる 1 次モード振動 からアトラクタが再構成され，そのアトラクタに対して計算される值である. また, \%RE $C_{1 \mathrm{st}}(s)$ は, 同様に第 $s$ 番目のセンサで獲得されるアトラクタに対して計算される\%RECであるが，この際，第 1 番目のセンサで獲得さ れた 1 次モード振動の標準偏差から計算された $\varepsilon_{1 \mathrm{st}}$ が闇值として使用される. 他の\%RE $C_{i \mathrm{th}}(s)$ も同様の手順で, 第 $i$ 番目のセンサで獲得された 1 次モード振動の標準偏差から決定された閾值 $\varepsilon_{i \mathrm{th}}$ を用いて, 第 $s$ 番目のセンサで獲 得されたアトラクタに対して計算される. 以上の手順により, 同一のアトラクタに対して, 複数の閾値を用いて, 複数の\%REC が計算される. 次に, これらの計算された各\%REC を用いて比を求め, 標準化された NRECを計算 し, Baseline データとしてNREC intact $(s)$ が獲得される. そして損傷診断時において, Step 1 から Step 4 が行われ, $\operatorname{NREC}_{i \text { th }}^{\text {damage }}(s)$ を獲得する. 最後に, Step 5 において損傷前後で NREC の比を求め, その最大值を損傷指標 (Damage Index: DI）として, 各計測点での DI 值から損傷位置を特定する. 本研究では, 健全時のデータおよび診断時にお 
いて計測されるデータを個々に評価することで，各状況で得られた NREC の減少・増加傾向などの相対関係を評 価し，その相対関係が損傷前後で異なることに着目したものである．損傷前後での NREC の相対関係の変化が DI 值として現れ，損傷を有する層が特定されると考えた． $\mathrm{DI}(s)=1$ の場合，第 $s$ 番目のセンサの近傍領域は健全 であると判断し, $\mathrm{DI}(s) \neq 1$ の場合, 第 $s$ 番目のセンサの近傍領域は何らかの損傷を有していると判断される.

\section{4. 実証試験}

本研究では，対象構造物として図 2(a)に示す頭頂部に起振機を有するアルミ合金製 4 層フレーム構造物を用い て, 表 2 に示寸損傷シナリオについて実証試験を行った。模型実験に先立ち, 本研究では図 2(a)に示したフレー ム構造物の寸法と表 3 に示寸構造諸元の下，モデル化を行い，動的解析を通じて提案手法の有用性を考察した. 数值実験では, 複数のモードが励起した層間加速度応答から前処理せずアトラクタを再構成し, 提案手法の手順 により DI 值を評価した場合の結果を明らかにし，1 次モード振動のアトラクタを評価することの有効性を示寸. 次に, 1 次モード振動のアトラクタを評価対象として, 健全時の情報から䦨值を決定し, 損傷前後で得られるア トラクタを交差させて，損傷位置を同定する方法と提案手法を比較する．なお，損傷は図 2(b)に示すセンサ S6 の右下の $\times$ 印で示された柱の幅を変更させたものを考え, S1 から S8 を応答の計測点とし, これらを挟む 2 つの 計算上の節点の応答の平均值を計測データとした. 例えば, S1 の応答には, 図中両隣の節点回の応答の平均值が 与えられる. またその際, 各節点で得られた応答加速度の標準偏差に対して $10 \%$ のきさのガウシアンノイズを それぞれに付加し，計測ノイズの発生を考慮した. 入力カオス信号としては数值実験及び模型実験ともに, 式(5) に示す 3 変数常微分方程式であるローレンツ方程式(24)を用いることとし, 図 $3(\mathrm{a})$ に示される第 1 変数である $z_{1}$ の 振動波形を起振機を通じて構造物に入力し, 各層に 2 つ配置した加速度センサにより応答を計測した. なお数值 実験では, 頭頂部の 4 つの節点に起振機の質量を負荷するとともに， カオス波形を地盤からの相対加速度として 入力した.

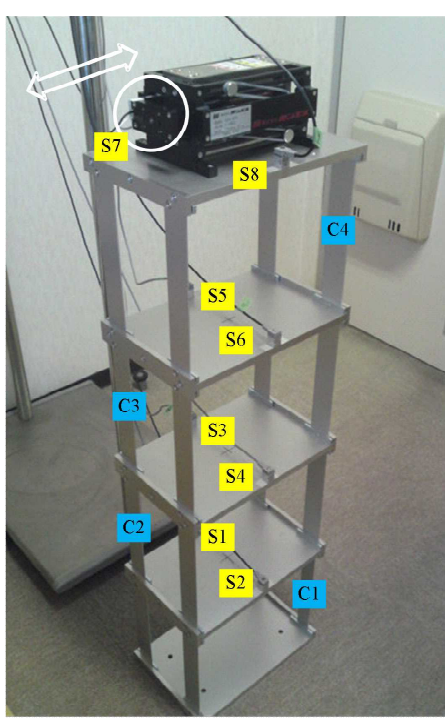

(a) Experimental model and exciter Fig.2 Structural model

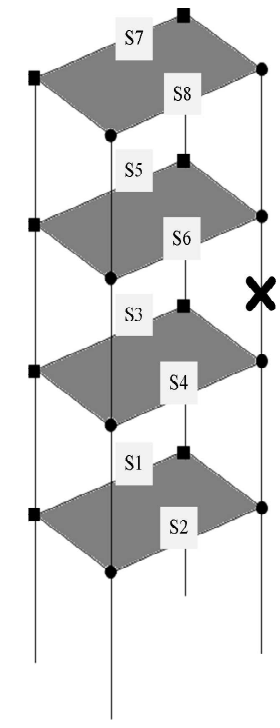

(b) Numerical model
Table 2 Damage scenario for laboratory experiments

\begin{tabular}{|c|c|}
\hline Scenario 1 & Remove column $\mathrm{C} 1$ \\
\hline Scenario 2 & Remove column C2 \\
\hline Scenario 3 & Remove column C3 \\
\hline Scenario 4 & Remove column C4 \\
\hline Scenario 5 & $\begin{array}{l}\text { Replace column C1 with a column } \\
\text { having the width of } 30 \mathrm{~mm}\end{array}$ \\
\hline Scenario 6 & $\begin{array}{l}\text { Replace column C2 with a column } \\
\text { having the width of } 30 \mathrm{~mm}\end{array}$ \\
\hline Scenario 7 & Remove column $\mathrm{C} 1$ and column $\mathrm{C} 3$ \\
\hline Scenario 8 & $\begin{array}{l}\text { Replace column } \mathrm{C} 1 \text { and column } \mathrm{C} 3 \\
\text { with columns having the width of } \\
30 \mathrm{~mm}\end{array}$ \\
\hline
\end{tabular}

Table 3 Structural property

\begin{tabular}{|l|l|}
\hline $\begin{array}{l}\text { Column size } \\
\text { (height,width,thickness) }\end{array}$ & $235 \times 40 \times 1.5(\mathrm{~mm})$ \\
\hline Slab & $300 \times 200 \times 12(\mathrm{~mm})$ \\
\hline Young's modulus $E$ & $70 \mathrm{GPa}$ \\
\hline Density $\rho$ & $2800 \mathrm{~kg} / \mathrm{m}^{3}$ \\
\hline Poisson's ratio & 0.28 \\
\hline $\begin{array}{l}\text { Damping ratio for the } 1 \mathrm{st} \\
\text { and 2nd mode }\end{array}$ & 0.01 \\
\hline
\end{tabular}




$$
\begin{aligned}
& \eta^{-1} \frac{d z_{1}}{d t}=-16\left(z_{1}-z_{2}\right) \\
& \eta^{-1} \frac{d z_{2}}{d t}=40 z_{1}-z_{2}-z_{1} z_{3} \\
& \eta^{-1} \frac{d z_{3}}{d t}=z_{1} z_{2}-4 z_{3}
\end{aligned}
$$

ここで, $\eta$ は入力信号の速度を変えるパラメータであり, $\eta$ を変えることで，カオス信号のリアプノフ指数と周波 数帯域を調整することができる. 本研究ではすべての実験で $\eta=1.0$ とした. また，サンプリング間隔を $0.01 \mathrm{~s}$ と して，45 秒間応答を計測した. なお，アトラクタを再構成する際の遅れ時間 $\tau=1$, 埋め込み次元 $m=3$ とし， DI 值を求める際に移動空法（空幅 : 1000 データ, 移動ステップ: 175, 解析結果 : 25 個の平均值) を用いて, 解 析結果の信頼性の向上を図った.また，1 次モード振動を抽出する際のマザーウェーブレットとして，本研究で はすべての実験でメイエのウェーブレットを使用した.

\section{$4 \cdot 1$ 数值実験}

数值実験では, 損傷として図 2(b)に示す 3 層の 1 つの柱部材の幅を健全時 $40 \mathrm{~mm}$ のものから $30 \mathrm{~mm}$ および $35 \mathrm{~mm}$

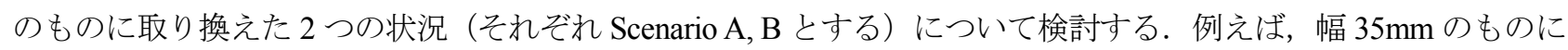
取り換えた場合, 部材諸元から計算すると層剛性の低下率は $3.125 \%$ であり, 固有值解析により計算される振動数 の変化で最も大きいのは加振方向に対するせん断 4 次モードとなった. ただしそれらの振動数の変化は健全時 $10.404 \mathrm{~Hz}$ に対し，損傷時 $10.335 \mathrm{~Hz}$ であり，変化率はおよそ $0.66 \%$ と極めて小さいことが確認された. 図 4 に健全 時のセンサ S1 で計測された応答加速度とその FFT 結果を示している。これらの結果から明らかなように，減衰 を与えたことにより 4 次モードは明確に確認できず，振動数の違いから損傷位置を同定することは容易ではない ことが分かる.なお，せん断 1 次モードの振動数の変化率は $0.36 \%$ となる.また，図 5 に 1 で計測される層間加 速度応答から 1 次モード相当の Wavelet 係数を抽出した結果とその FFT 結果を示す. FFT 結果から明らかなよう に得られた Wavelet 係数は 1 次モード相当の振動波形を表していると考えることができる.

図 6 は 3 層の 1 つの柱部材（センサS6 の右下）を幅 30mm のものに取り換えた状況(Scenario A)に対し，層間 加速度応答から前処理せずアトラクタを再構成し，提案手法の手順により DI 值を評価した場合の結果(図 6(a))お

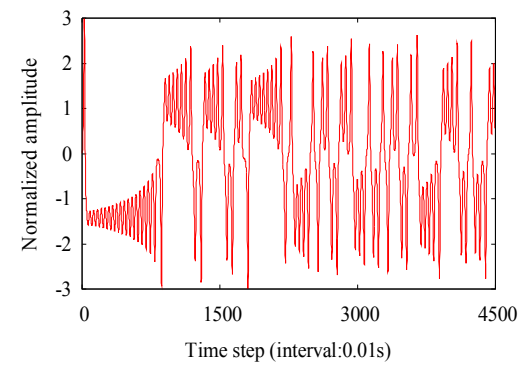

(a) First variable of Lorenz system

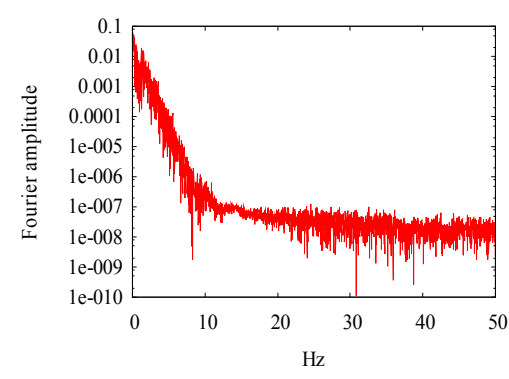

(b) Fourier spectra of input signal

Fig. 3 chaotic excitation

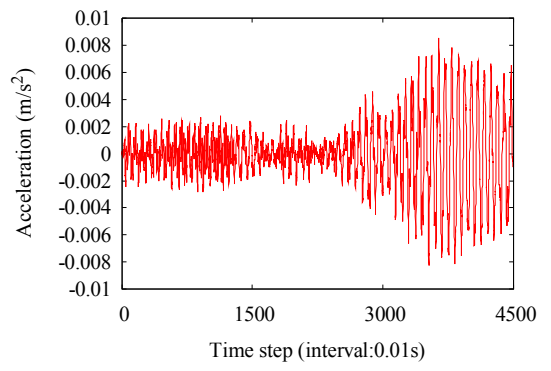

(a) Time history of original signal

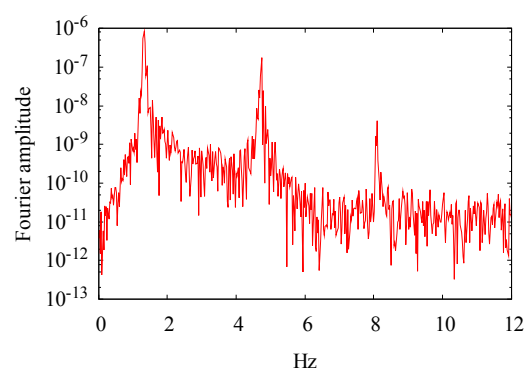

(b) Fourier spectra of original signal

Fig.4 Response in time and freq. domain Fig.5 Wavelet coefficients

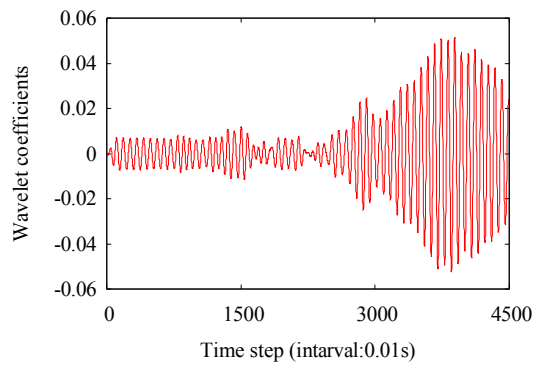

(a) Time history of wavelet coefficients

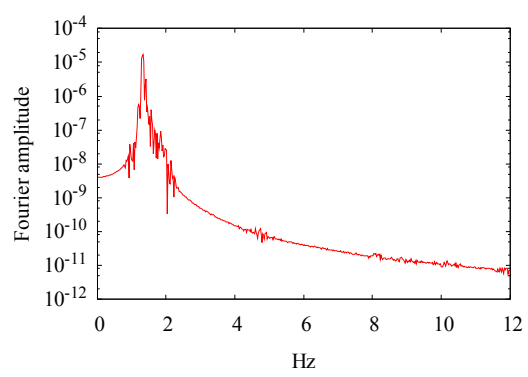

(b) Fourier spectra of wavelet coef. 
よび損傷前後の 1 次モード振動のアトラクタを交差させ，健全時の 1 次モード振動から閾值を決定した場合の結 果(図 6(b))を示している．これらの図の縦軸はDI 值であり，横軸はセンサ番号である.

層間加速度応答そのものからアトラクタを再構成し, 提案手法の DI 值を評価する方法では, 図 6(a)から明らか なように損傷位置に最も近いセンサ S6 の DI 值が最も大きな值を示しているものの, 他の健全な層（第 1 層, 第 4 層）の応答を計測するセンサ S1，S2，S7，S8 も概ね 1.10 を示し，健全時と比較して $10 \%$ ま゙゙変化しており， 健全であるのか損傷を有するのか判断は困難である.これは前記したように, 複数のモードが励起した場合, 寸 べての計測データが健全時と比較して複雑に変化することが理由として考えられる. そして, 1 次モード振動の アトラクタを評価対象として, 健全時の情報から䦨值を決定し，アトラクタを交差させて評価する方法では, 図 6(b)から明らかなように, 損傷位置に最も近いセンサ S6 の DI 值が最も小さい值を示しているものの, 他の健全 な層の応答を計測するセンサについても 1.0 より小さな值を示し, どの領域が損傷しているのか健全であるのか 判断することは容易ではない.

図 7 に, 対象構造物が診断時において健全である状況およびScenario A, Scenario B に対して, 提案手法を適用 した結果を示す．対象構造物が診断時に健全である状況では，図 7(a)に示されるように，DI 值は多少のばらつき は認められるものの，すべての計測点で概ね 1.0 を示していることが分かる. このことは Baseline データに対し て変化がなく, 対象の構造特性に変化がないことを意味している. 一方, 図 7(b)に示す Scenario A に関しては, 損傷を有する第 3 層の応答を計測する 2 つのセンサの内, S6 の DI 值が最も大きい值を示し, Baseline データに 対して概ね 16\%上昇していることが分かる．また，他の健全な層に配置されているセンサについては，多少のば らつきは認められるものの概ね 1.0 を示しており, 損傷の影響を受けることなく, 損傷前後で変化していないと 考えることができる．これらのことから，第 3 層に何らかの異常があることが予測される．この損傷パターンは センサ S6 の右下の柱の幅を 10mm 細くした状況であるが，S5 についても，他の健全な層の応答を計測するセン サで得られる DI 值よりわずかであるが大きな值を示している.これは損傷の影響が S5 にも表れたことが理由と して考えられる. 図 7(c)に示寸第 3 層の 1 つの柱部材を幅 $35 \mathrm{~mm}$ のものに取り換えた状況（Scenario B）に関して は, 第 3 層の応答を計測する 2 つのセンサの内, S6 が最も大きい值を示し, Baseline データに対して概ね $7 \%$ 上 昇することが確認できる，一方，他の健全な層に配置されているセンサについては，多少のばらつきは認められ るものの概补 1.0 を示しており, 損傷の影響を大きく受けることなく, 損傷前後で変化していないことが示唆さ れる.これらのことから，第 3 層に何らかの異常が存在することを予測できる. また，柱幅を $5 \mathrm{~mm}$ および $10 \mathrm{~mm}$ 細くした場合を比べると，5mm 細くした場合の方が，S6の DI 值は小さいことから，損傷の規模と損傷が存在す

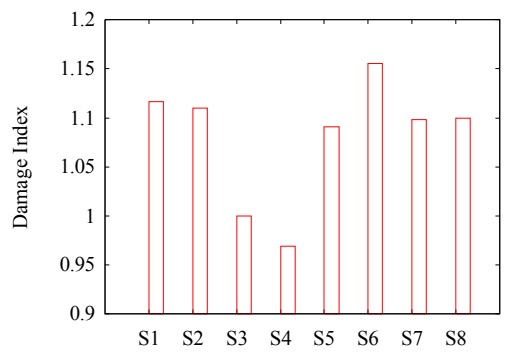

(a) DI calculated from original response

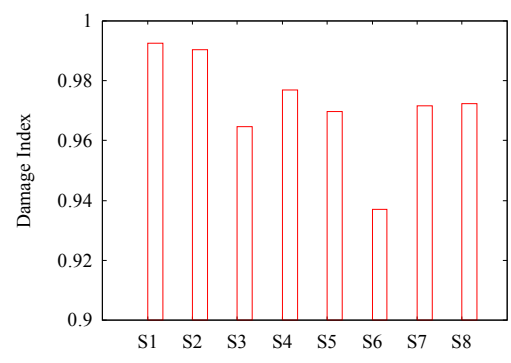

(b) DI calculated from cross $\% R E C$

Fig.6 Damage Index by previous studies for scenario A

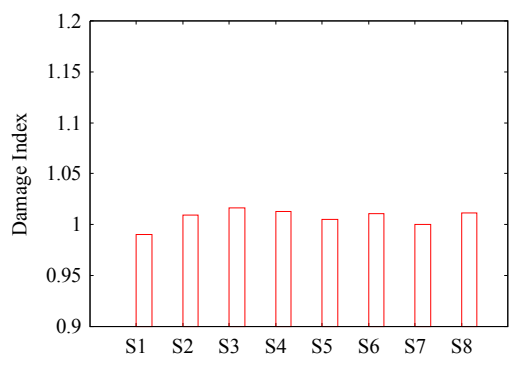

(a) Intact case

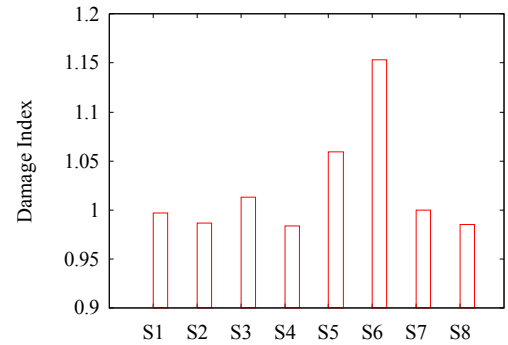

(b) Scenario A

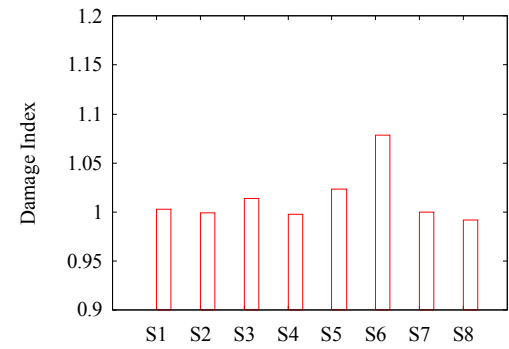

(c) Scenario B

Fig.7 Damage Index by the proposed system 
る近傍のセンサで得られる DI 值に相関があることが予測される. 以上の結果から，1 次モード振動に着目し，健 全時のデータおよび診断時において得られた NREC の減少・増加傾向などの相対関係を評価することが損傷位置 同定に有効であることが分かる，なお，提案手法において，損傷を有する層の応答を計測するセンサでの DI 值 が Baseline データに対して上昇する（DI>1.0）理由は模型実験の結果を通じて明らかにする.

\section{$4 \cdot 2$ 模型実験}

損傷シナリオについては表 2 に示した 8 ケースについて検討する.ここで，柱部材を一本除去する場合の層剛 性の低下は $25 \%$ であり, 柱部材の幅が $10 \mathrm{~mm}$ 細い場合, 部材諸元から計算すると層剛性の低下率は $6.25 \%$ となる. 例えば，第 1 層の柱を幅 $10 \mathrm{~mm}$ 細いものに取り換えた場合, 振動応答から計算される卓越振動数の変化は最も大 きいのは 2 次モードとなった．ただしそれらの変化は健全時 $4.712 \mathrm{~Hz}$ に対し，損傷時 $4.663 \mathrm{~Hz}$ であり，その変化 の比率はおよそ $2 \%$ と大きくはなく, 振動数の変化から損傷位置を同定することは容易ではない. また，柱を計 2 本除去した場合は，かなり大規模な損傷であり，現実的な設定ではないと思われるが，このような条件下でも提 案手法で定める DI 值が有効に機能するか確認寸ることとした，なお，参考として，診断時に対象構造物が健全 である状況での結果を図 8 に示す．前述の数值計算での結果と同様，多少のばらつきは認められるものの，す心゙ ての計測点での DI 值が概ね 1.0 を示し，構造特性は Baselineデータ取得時と変化がないことを示している.

\section{$4 \cdot 2 \cdot 1$ 損傷が 1 つ存在する場合}

図 9 に損傷シナリオ 1 (第 1 層の柱, 図 2(a)中 $\mathrm{C} 1$ を除去)の結果を示寸. 第 1 層の応答を計測する $\mathrm{S} 1, \mathrm{~S} 2$ が最も 大きく, Baselineデータ（健全時データ）に対して概ね 100\%上昇していることが分かる，一方，他の健全な層に 配置されているセンサでは多少のばらつきは認められるものの概ね 1.0 を示しており，損傷の影響を受けること なく, 損傷前後で変化していないことが分かる.これらのことから, 第 1 層に何らかの異常があることが予測さ れる．この損傷シナリオ 1 はセンサ S2 の右下の柱を除去した状況であるが，S1 と S2 の DI 值にほとんど違いが 見られなかった. これは損傷の規模が大きく, 2 つのセンサで計測される応答にほぼ違いが見られなかったこと が理由として考えられる．また，本研究では各層に 2 つ加速度計を配置しているが，層レベルで損傷位置を同 定する場合，センサは各層一つで十分であることを付記しておく.

図 10 に損傷シナリオ 2 (第 2 層の柱，図 2(a)中 C2 を除去)の結果を示寸. DI 值を確認すると，S3, S4 の DI 值が 全体の中で最も大きく, Baseline データに対して約 100\%上昇していることが分かる. 一方，他の健全な層の応答 を計測するセンサでは多少のばらつきは認められるものの，概ね 1.0 を示している．これらの層の構造特性は Baseline データ取得時と変化がないことを意味している. 以上のことから, 第 2 層に何らかの異常があると判断 できる. 図 11 および図 12 に示される損傷シナリオ 3,4 についても同様の結果が得られ，損傷位置を DI 值の大 きさから判断できることが分かる.

次に，第 1 層の柱，図 2(a)中の柱 $\mathrm{C} 1$ の幅を $10 \mathrm{~mm}$ 細くしたものに取り換えた状況である損傷シナリオ 5 の結 果を図 13 に示寸. 第 1 層のセンサ S1, S2 の DI 值が全体の中で最も大きく, Baseline データに対して概ね 20\%ほ ど上昇していることが分かる. 一方, 他の健全な層から得られる DI 值は, 多少のばらつきが認められるものの, おおむね定值 1.0 を示しており, 損傷前後で変化がないことが分かる.

第 2 層の柱, 図 2(a)中の柱 $\mathrm{C} 2$ の幅を $10 \mathrm{~mm}$ 細くしたものに取り換えた状況である損傷シナリオ 6 の結果を図 14 に示寸．第 2 層のセンサ S3, S4 の DI 值が全体の中で最も大きく, Baseline データに対して概ね $20 \%$ ほど上昇 していることが分かる，一方，他の健全な層から得られる DI 值は，多少のばらつきが認められるものの，おお む社一定值 1.0 を示しており，損傷前後で構造特性に変化がないことが分かる．以上のことから，本研究で提案 寸る\%REC から計算される Damage Index を評価することで，層剛性の低下レベルが 6\%程度であれば，十分にそ の位置を特定することが可能であることが分かる.

\section{$4 \cdot 2 \cdot 2$ 損傷が 2 つ存在する場合}

図 15 に損傷シナリオ 7(第 1 層の柱 $\mathrm{C} 1$ と第 3 層の柱 $\mathrm{C} 3$ を除去) の結果を示す. DI 值を確認すると, 第 1 層の 応答を計測する S1, S2 および第 3 層の応答を計測する S5, S6 の DI 值が全体の中で大きく, Baseline データに対し て約 80\%から 100\%上昇していることが分かる．一方，他の健全な層の応答を計測する S3，S4，S7，S8 センサで 


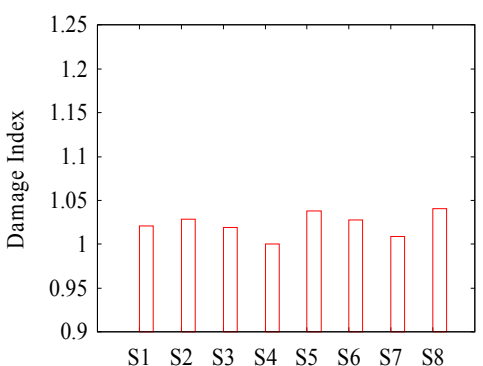

Fig.8 Results for intact case

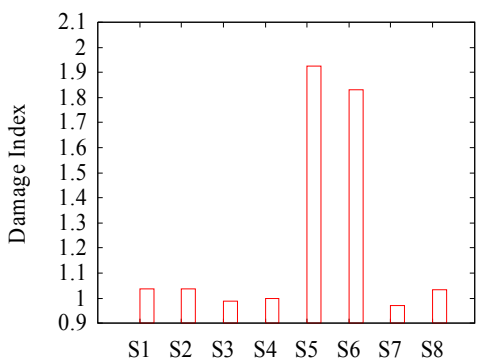

Fig.11 Results for scenario 3

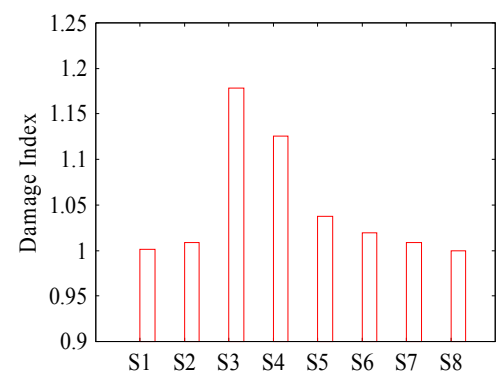

Fig.14 Results for scenario 6

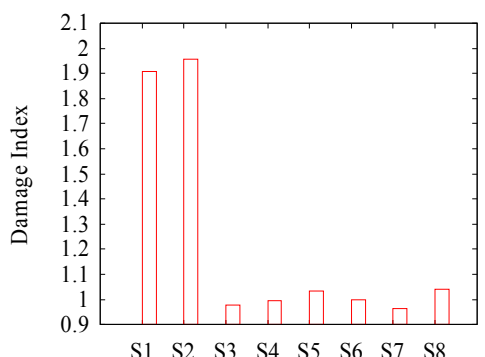

Fig.9 Results for scenario 1

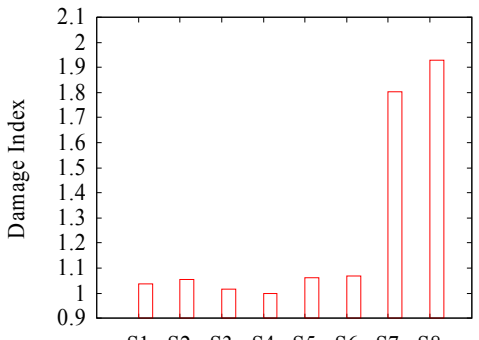

Fig.12 Results for scenario 4

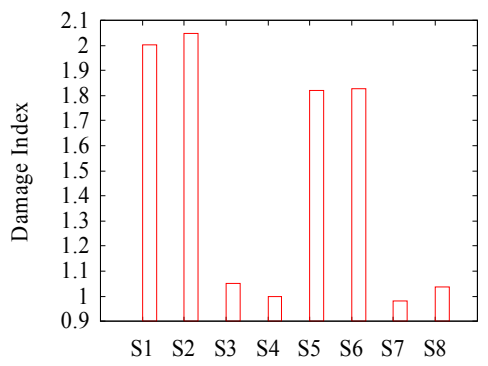

Fig.15 Results for scenario 7

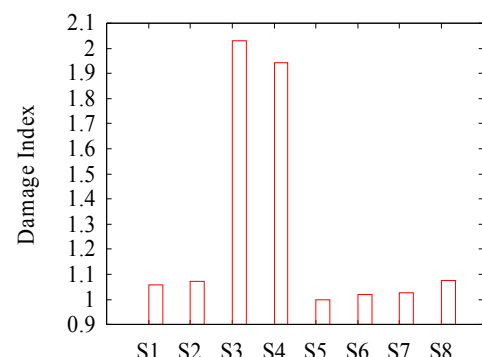

Fig.10 Results for scenario 2

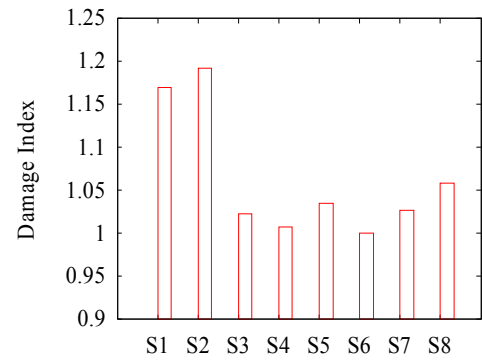

Fig.13 Results for scenario 5

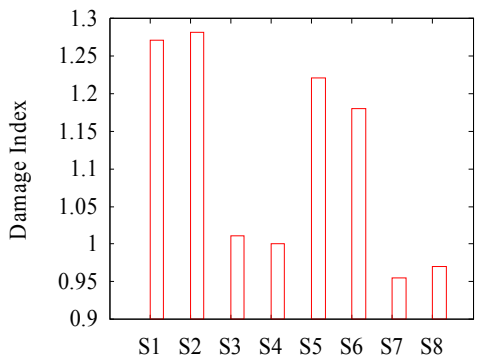

Fig.16 Results for scenario 8

は多少のばらつきは認められるものの，概ね 1.0 を示している．このことは，健全な層の応答は第 1 層および第 3 層に発生した損傷の影響を受けず，損傷前後で構造特性に変化がないことを意味している.

次に, 損傷シナリオ 8 (第 1 層の柱 $\mathrm{C} 1$ と第 3 層の柱 $\mathrm{C} 3$ をそれぞれ, 幅を $10 \mathrm{~mm}$ 細くした柱に取り換えた状況) の結果を図 16 に示す。 1 層のセンサ S1, S2 および 3 層のセンサ S5, S6 の DI 值が全体の中で大きく，Baseline デ 一タに対して，概ね 15\%から 25\%ほど上昇していることが分かる，一方，他の健全な層から得られる DI 值は， 多少のばらつきが認められるものの，おおむね一定值 1.0 を示しており，損傷前後で構造特性に変化がないこと

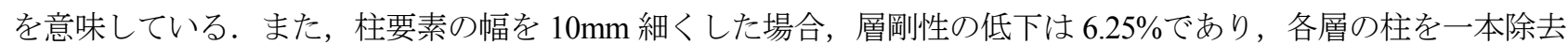
した場合に比べて損傷の規模は小さい. 損傷規模が小さくなるに従って，DI 值も小さくなる傾向が，数值実験結 果と同様に示された.

\section{$4 \cdot 2 \cdot 3$ 損傷位置同定のメカニズム}

提案手法を適用することで，損傷を有する層での DI 值が 1.0 より大きく，健全な層での DI 值は概ね 1.0 を示 すことが数值実験および模型実験を通じて確認された．本項では，損傷シナリオ1の結果を例として，損傷を有 する層の応答を計測するセンサでの DI 值が Baseline データに対して上昇する（DI $>1.0 ）$ 理由を考察する. 提案手 法では，DI 值は損傷前後の応答から計算される $\mathrm{NREC}_{i \mathrm{th}}(\mathrm{s})\left(=\% R E C_{\mathrm{own}}(\mathrm{s}) / \% R E C_{i \mathrm{th}}(\mathrm{s})\right)$ の比と定義される. 評価対 
象のデータを計測したセンサと閾值 $\varepsilon_{i \mathrm{th}}$ を決定する際のデータを計測したセンサが一致する場合 ( $s=i$ の場合), 同じ計測データの標準偏差から閾值 $\varepsilon_{\mathrm{own}}$ と $\varepsilon_{i \mathrm{th}}$ が決定され, それらは同值であることから, $\operatorname{NREC}_{i \mathrm{th}}(\mathrm{s})=1$ となる. 一方, $s \neq i$ である場合, 評価対象のセンサ $\mathrm{s}$ のデータに対して, 異なる 2 つ閾值を用いて, リカレンスポイ ントがカウントされるため, 結局, NREC $\neq 1$ となる.

図 17 にNREC $\mathrm{Nimage}_{i \mathrm{~h}}^{\mathrm{dam}}(s) / \operatorname{NREC}_{i \mathrm{th}}^{\mathrm{intact}}(s)$ の結果を示し, その中から, 図 18 に示される $\mathrm{NREC}_{6 \mathrm{th}}\left(=\% R E C_{\mathrm{own}} / \% R E C_{6 \mathrm{th}}\right)$ を例として説明する。 なお，図 17 において，各センサでの最大值が DI 值となる. $\mathrm{NREC}_{6 \mathrm{~h}}$ は健全時および損傷

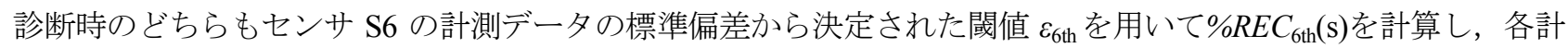
測点のデータの標準偏差から決定された $\varepsilon_{\mathrm{own}}$ を用いて算出された $\% R E C_{\mathrm{own}}(\mathrm{s})$ を標準化した結果である. 健全時お よび損傷時のどちらも $\mathrm{S} 6$ の $\mathrm{NREC}_{6 \mathrm{th}}$ が 1.0 を示している. そしてそれ以外の計測点では $\mathrm{NREC}_{6 \mathrm{th}} \neq 1.0$ となり, 損 傷前後で比較すると, 損傷を与えた第 1 層の応答を計測するセンサ $\mathrm{S} 1, \mathrm{~S} 2$ の $\mathrm{NREC}_{6 \mathrm{th}}$ が健全時のそれと比較して, 上昇していることが分かる. センサ $\mathrm{S} 1$ の $\mathrm{NREC}_{6 \mathrm{th}}$ が健全時に対し, 上昇した理由は wavelet 係数の標準偏差から 明らかである. 図 19 にその標準偏差を示寸. 損傷時では S1 で得られた Wavelet 係数の標準偏差が S6 のそれより かなり大きな值を示している.これらの標準偏差から決定される閯値の大小関係は $\varepsilon_{\mathrm{own}} \geq \varepsilon_{6 \mathrm{th}}\left(\varepsilon_{\mathrm{own}}\right.$ は S1 で得られ た標準偏差 $\times 0.1 ， \varepsilon_{6 \mathrm{th}}$ は S6 で得られた標準偏差 $\left.\times 0.1\right)$ であり，損傷時の S1 の Wavelet 係数に対して $\mathrm{NREC}_{6 \mathrm{th}}$ $\left(=\% R E C_{\mathrm{own}} / \% R E C_{6 \mathrm{th}}\right)$ を計算すると, 閾值が大きくなるにつれて, 式(2)のリカレンスポイントが増加することか ら，NREC>1.0 となることが明らかである. S1の Wavelet 係数に対して計算される実際の Auto Recurrence Plots の結果の違いを図 20 に示寸. 図 20(a)はディスタンスマトリックス $D_{i, j}$ を計算する際の閾値を $\varepsilon_{\mathrm{own}}$ とした場合(case

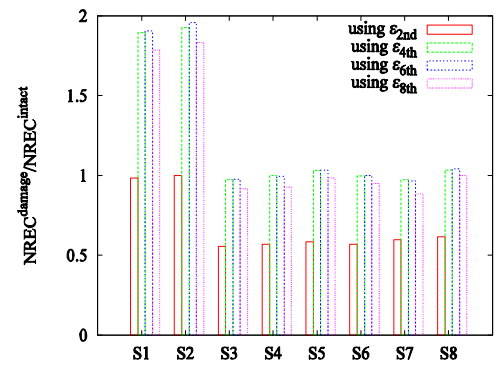

Fig.17 Ratio of NREC for scenario 1

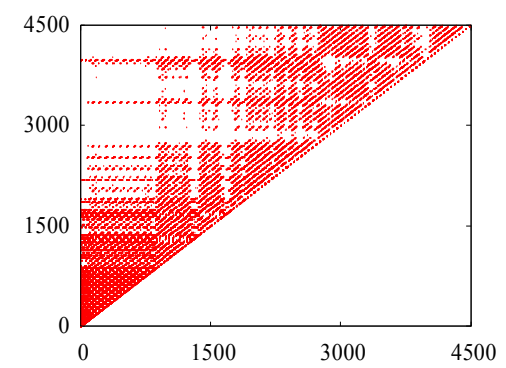

(a) case 1

Fig.20 Difference of Recurrence plots

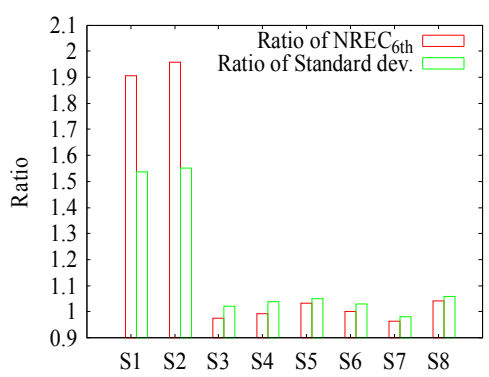

Fig.21 Comparison of DI vs. STD

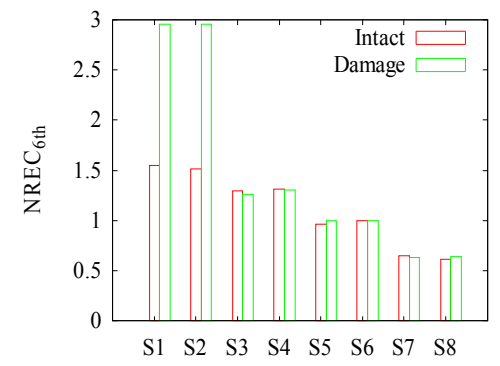

Fig.18 NREC $_{\text {th }}$ for scenario 1

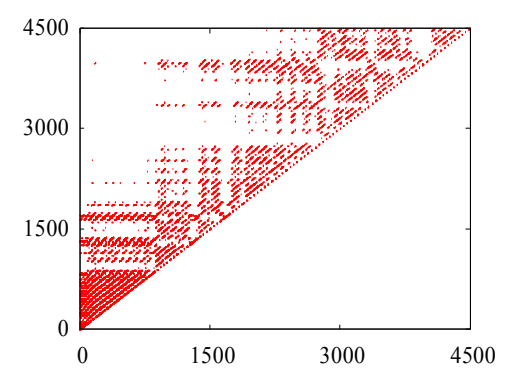

(b) case 2

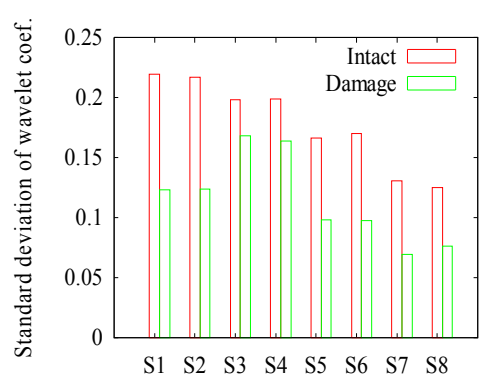

Fig.22 Standard deviation (scenario 2)

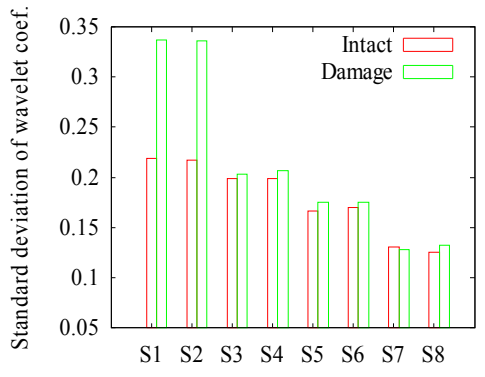

Fig.19 Standard deviation (scenario 1) 
1)の結果を示し，図 20(b)は閾値を $\varepsilon_{6 \mathrm{th}}$ とした場合(case 2)の結果を示寸．これらの図から明らかなように，大きい 閾值 $\varepsilon_{\mathrm{own}}$ を用いた case 1 の方が， case 2 より明らかにリカレンスポイントの密度が高いことが分かる，一方，健 全時では, Wavelet 係数の標準偏差は S1 から S8 にかけて減少傾向を示している. S6 での Wavelet 係数の標準偏 差から決定される䦨値 $\varepsilon_{6 \mathrm{th}}$ を用いて各センサで計算される\%REC $C_{\mathrm{own}}$ を標準化すると，閾值の大小関係から明らか なように, 第 3 層の S6 では 1.0 となり, 第 3 層より下位に位置寸る第 1 層, 第 2 層のセンサ $\mathrm{S} 1$ から $\mathrm{S} 4$ では, $\mathrm{NREC}>1.0$ となり第 3 層より上層では $\mathrm{NREC}<1.0$ となることが分かる.つまり第 1 層から上位層に向かって, NREC は緩やかに減少していく様子が認められる. 本研究で提案する NREC は\%REC の比であり，\%RECの值は閾值に 依存する，そして，閾值は Wavelet 係数の標準偏差から決定され，各センサの標準偏差の増減の相対関係が損傷 前後で異なることから，結果としてそれらの変化はNRECに現れることとなる.

以上を踏まえ，損傷を有する層の DI 值が Baseline データに対して上昇する（DI>1.0）理由は Wavelet 係数の標 準偏差から推測できる. 本研究では, 塔上構造物の層間加速度の 1 次モードの振動成分を評価している. 図 19 から明らかなように, Wavelet 係数の標準偏差を損傷前後で比較すると，損傷を有する第 1 層のみが Baseline（健 全時）に対して大きい. このことは，1 次モードは節が存在せず，損傷を有する第 1 層の剛性の低下に起因して， その層の応答が増加したことが理由として考えられる.また, 他の層の Wavelet 係数の標準偏差は損傷前後で変 化がない理由は，上位の層と下位の層の応答の差（相対加速度）を上位の層の層間応答として評価していること から，第 1 層の損傷が上位の層の応答へ影響を与えなかったと考えられる．以上のことから，損傷を有する層は 1 次モードを評価する限り, 剛性低下に伴いその応答が増加し, 結果として NREC の相対関係が Baseline データ 取得時および診断時において変化し, NREC の比である DI 值が損傷を有する層で 1.0 より大きくなると考えられ る. また，この損傷シナリオ 1 の場合は, 結果として, 損傷前後で計算される Wavelet 係数の標準偏差の比から も損傷位置を同定可能であるが，損傷に対する感度が異なる. 図 21 に損傷前後で計算される Wavelet 係数の標準 偏差の比と DI 值を示す. 図から明らかなように, 提案手法により NREC の相対関係を損傷前後で比較する方が 損傷に対して感度が高いことが確認できる. そして，この損傷前後の Wavelet 係数の標準偏差の比からは，必ず しも損傷位置を同定できるとは限らないことに注意を要する. 図 22 に損傷シナリオ 2 で計算される Wavelet 係数 の標準偏差を健全時のものと合わせて示す．損傷時の結果では，損傷を与えた第 2 層で計測される Wavelet 係数 の標準偏差が他の層と比較して大きな值を示しているものの, 健全時の Wavelet 係数の標準偏差と比較して各計 測点での值が全体的に小さい傾向を示し，単純にそれらの比を計算するだけでは損傷位置は同定困難であること が分かる．損傷シナリオ 2 での Wavelet 係数の標準偏差が全体的に健全時のものより小さい傾向を示した理由は 卓越する振動モードが別のモードに変化したことが考えられる.

以上のことから，健全時のデータおよび診断時において計測されるデータを用いて，各状況下で計算される NREC の減少・増加傾向を相対的に評価し，これらの比の最大值で表される DI 值から，損傷を有する層のみが抽 出可能となることが確認され, 提案手法の有效性が実証された.

\section{5. 結言}

本研究では, カオス応答の 1 次モード成分に着目し, アトラクタの評価として Recurrence Quantification Analysis の内, リカレンスプロットを適用し，損傷位置同定を試みた．リカレンスプロットの評価指標である\%REC は計 算時の闇值の設定により変化することから, 本研究では複数の闇值を設定し\%REC 標準化することを考え, 健 全時および診断時の各状況下において算出される計測点間の\%RECの減少・増加などの相対関係を評価した. 数 值実験・模型実験を通じて, 損傷位置を同定寸ることに成功し, 提案手法の有効性が確認された. 以下に本研究 で得られた知見を整理するとともに，今後の課題を追記する.

・ 数值実験を通じて, 複数のモードが励起する層間加速度応答から前処理せずアトラクタを再構成し, それを 評価すると, 損傷を有する層の特定に失敗することが確認された. また, アトラクタをリカレンスプロット により評価する際, 健全時の情報により閾值を決定し, 損傷前後のアトラクタを交差して評価すると, 損傷 位置の同定が困難となることが確認された。 
・層間加速度の Wavelet 係数で表現される 1 次モード相当の振動成分を評価の対象とし, それらのアトラクタ のリカレンスプロットから\%REC を計算した結果，損傷位置同定が正確に行えた.

・ \%REC を計算する際の闇值 $\varepsilon$ を, 各センサで計算されるそれぞれの Wavelet係数の標準偏差から設定し,\%REC を標準化した複数の NREC を Baseline データとする.この Baseline データと診断時に得られた NREC との比 の最大值を選択して評価に用いることで, 損傷を有する層を特定できた.

今後の取り組むべき課題として, 損傷程度と Damage Index の関係を定量的に把握することが重要であると考え る．提案手法では層剛性の低下率に対して，感度良く損傷を有する層を特定することに成功したが，損傷程度は 不明である. 今後は提案手法により損傷の可能性のある領域を特定した後に，診断対象への入出力データを用い て，粒子フィルタ等のデータ同化技術により層剛性など損傷程度を同定することを試み，使用性・安全性に影響 を与える損傷かどうかを判断するシステムの開発を目指寸予定である．また，本研究では，診断対象として，塔 状の線形 4 層フレーム構造物を使用したが，今後は橋梁モデルなどの梁部材へ適用することなど，さらに複雑な モデルを使用した数值実験や模型実験等を実施し, 提案手法の有用性を明らかにすることが重要であると考える. また，新たな取り組みとして，入力カオス信号と診断対象の応答を同時に評価し，Baseline データを必要としな い Baseline-Free 型の損傷診断法の開発を目指寸予定である.

\section{文献}

（1）魚本健人，加藤潔，広野進，コンクリート構造物の非破壊検査（1990），森北出版.

(2) 宮本文穂，河村圭，中村秀明，“Bridge Management System(BMS)を利用した既設橋梁の最適維持管理計画の策定”, 土木学会論文集, No.588/VI-38 (1998), pp.191-208.

(3) 中村秀明, 白倉篤志, 宮本文穂, “階層構造モデルを用いた構造物維持管理支援システムの実用化”, 土木学会論文 集, No.777/VI-65 (2004), pp.125-138.

(4) Doebling, S.W., Farrar, C.R. and Prime, M.B., "A summary review of vibration-based identification methods", The Shock and Vibration Digest, Vol.30, No.2 (1998), pp.91-105.

(5) Farrar, C.R., Duffey, T.A., Doebling, S.W. and Nix, D.A., "A statistical pattern recognition paradigm for vibration-based structural health monitoring”, in: Structural Health Monitoring 2000, (1999), pp.764-773.

(6) Verboven, P., Parloo, E., Guillaume, P. and Van, O.M., "Autonomous structural health monitoring: part I, modal parameter estimation and tracking”, Mechanical Systems and Signal Processing, Vol.16, Issue 4 (2002), pp.637-657.

(7) Bohle, K. and Fritzen, C.P., "Results obtained by minimizing natural frequency and mac-value error of a plate model", Mechanical Systems and Signal Processing, Vol. 17, Issue 1 (2003), pp.55-64.

（8）中村充，竹脇出，安井挔，上谷宏二，“限定された地震観測記録を用いた建築物の剛性と減衰の同時同定”, 日本建 築学会構造系論文集, No.528 (2000), pp.75-82.

(9) Mita, A., "Distributed health monitoring system for a tall building", Proceedings of $2^{\text {nd }}$ International Workshop on Structural Control (1996), pp.333-340.

(10) 吉元怜毅, 三田彰, 森田高市, “振動モードとセンサ特性を考慮した構造物の並列処理型損傷同定”, 日本建築学会 構造工学論文集, Vol.48B (2002), pp.487-492.

(11) Sohn, H., Farrar, C.R., Hunter. N.F. and Worden, K., "Structural health monitoring using statistical pattern recognition techniques", Journal of Dynamic Systems, Measurement, and Control, Vol. 123 (2001), pp.706-711.

(12) Bodeux, J.B. and Golinval, J.C., "Modal identification and damage detection using the data-driven stochastic subspace and arma methods", Mechanical Systems and Signal Processing, Vol. 17, Issue 1 (2003), pp.83-89.

(13) Worden, K., Manson, G. and Allman, D., "Experimental validation of a structural health monitoring methodology: part I, novelty detection on a laboratory structure", Journal of Sound and Vibration, Vol. 259, Issue 2 (2003), pp.323-343.

(14) Okafor, A.C. and Dutta, A., "Structural damage detection in beams by wavelet transforms", Smart Materials and Structures, Vol.9, No.6 (2000), pp.906-917. 
(15) Hou, Z., Noori, M. and Amand, R.St., "Wavelet-based approach for structural damage detection", Journal of Engineering Mechanics, ASCE, Vol. 126, Issue 7 (2000), pp.677-683.

(16) Kim, H. and Melhem, H., "Damage detection of structures by wavelet analysis", Engineering Structures, Vol.26 (2004), pp.347-362.

(17) Nichols, J.M., Todd, M.D., Seaver, M. and Virgin, L.N., "Use of chaotic excitation and attractor property analysis in structural health monitoring", Physical Review E, Vol. 67 (2003), pp.016209 1-8.

(18) Nichols, J.M., Trickey, S.T., Todd, M.D. and Virgin L.N, "Structural Health Monitoring through Chaotic Interrogation", Meccanica, Vol.38 (2003), pp.239-250.

(19) Nichols, J.M., Virgin, L.N., Todd, M.D. and Nichols, J.D., "On the use of attractor dimension as a feature in structural health monitoring”, Mechanical System and Signal Processing, Vol. 17, Issue 6 (2003), pp.1305-1320.

(20) 佐藤忠信, 田中庸平, “構造物のカオス応答アトラクタを用いた損傷検出法の開発”, 土木学会論文集 A, Vol. 62, No.4 (2006), pp.915-924.

(21) 野村泰稔, 古田均, 川谷充郎, 広兼道幸, 中津功一朗, “力オス信号入力と交差予測誤差率による構造物の応答評 価に基づく損傷診断法の開発”，土木学会論文集 A, Vol.65, No.1 (2009), pp.30-41.

(22) Eckmann, J.P., Kamphorst, D., and Ruelle D., “ Recurrence plots of dynamic systems”, Europhysics Letter, Vol. 4 (1987), pp.973-977.

(23) Webber Jr., C.L. and Zbilut, J.P., "Dynamical assessment of Physiological systems and states using recurrence plot strategies", Journal of Applied Physiology, Vol.76 (1994), pp.965-973.

(24) Lorenz, E.N., "Deterministic Nonperiodic Flow”, Journal of the Atmospheric Sciences, Vol. 20 (1963), pp.130-141. 